РОЗДІЛ 10

СУДОУСТРІЙ; ПРОКУРАТУРА ТА АДВОКАТУРА

УДК 347.78

DOI https://doi.org/10.32782/2524-0374/2021-1/74

\author{
ТЕОРЕТИКО-ПРАВОВІ АСПЕКТИ ВИКОРИСТАННЯ РЕКЛАМИ \\ ЯК ОБ'ЄКТА АВТОРСЬКОГО ПРАВА
}

\title{
THEORETICAL AND LEGAL ASPECTS OF USING ADVERTISING AS AN OBJECT OF COPYRIGHT
}

\author{
Коваленко Д.О., студентка II курсу \\ Навчально-науковий інститут права \\ Сумського державного університету
}

Уткіна М.С., к.ю.н., старший викладач кафедри кримінально-правових дисциплін та судочинства

Сумський державний університет

\begin{abstract}
Світ розвивається швидкими темпами, оволодіваючи новими технологіями, освоюючи нові професії та даючи нові можливості. Масштаби прогресу потребують відповідних моделей його забезпечення та просування. Сьогодні будь-яка діяльність не обходиться без розширення своїх меж і популяризації серед населення. Основним сучасним методом просування послуг, продукції, діяльності та будь-якого інформування є реклама. Нині ця сфера має широке розгалуження, що полягає у різних видах реалізації реклами та сфрерах її застосування. Реклама - це безмежна платформа, у реалізації якої використовуються різноманітні об’єкти інтелектуальної власності, що, у свою чергу, потребують відповідного законодавчо правильного застосування та регламентації. Рекламна інформація націлена на формування чи підтримку інтересу до осіб, які згадуються в ній, і (чи) продукції, сприяє реалізації продукції, впливає на потенційних споживачів реклами, формує в них певне уявлення про конкретних фрізичних і юридичних осіб, спрямована на невизначене коло споживачів. Отже, одержання прибутку є метою не реклами, а рекламодавця, для здійснення якої він поширює рекламну інформацію, тобто здійснює рекламну діяльність. Тому мета реклами призначена сформувати або підтримати обізнаність споживачів реклами та їхній інтерес до такої особи чи сприяння продажу, купівлі, оренді товару, або спрямована на досягнення соціального результату бажаного для рекламодавців. Через потреби суспільства й основні засади рекламної індустрії, її популярність і необхідність у сучасному суспільстві актуалізується питання щодо окремих аспектів реалізації рекламної діяльності. У контексті здійснення своєї діяльності рекламісти або особи, які займаються таким просуванням, допускають значних помилок, зокрема щодо реалізації свого продукту за допомогою залучення різних видів об'єктів інтелектуальної власності. Здебільшого такі помилки трактуються як порушення права інтелектуальної власності. 3 огляду на це тематика $є$ актуальною та становить предмет дослідження для науково-дослідної роботи. У статті було проаналізовано поняття реклами як виду інформації, визначено та проаналізовано її ознаки та законодавчі вимоги до реклами як виду інформації. Автори визначили рекламну продукцію як об'єкт авторського права. Також було проаналізовано нормативно-правову базу становлення у сфері правового регулювання реклами.

Ключові слова: авторське право, об'єкт авторського права, реклама, рекламна продукція.
\end{abstract}

The world is developing rapidly, mastering new technologies, mastering new professions and providing new opportunities. The scale of progress requires appropriate models for its provision and promotion. Today, any activity is not without expanding its boundaries and popularization among the population. The main modern method of promoting services, products, activities and any information is advertising. Currently, this area has a wide range, which consists of different types of advertising and areas of its application. Advertising is a limitless platform, in the implementation of which various objects of intellectual property are used, which, in turn, require appropriate legal application and regulation. Advertising information is aimed at forming or maintaining interest in the persons mentioned in it, and (or) products, promotes sales, affects potential consumers of advertising, forms in them a certain idea of specific individuals and legal entities, aimed at an indefinite range of consumers. Thus, making a profit is not the purpose of advertising, and the advertiser for which he disseminates advertising information, ie carries out advertising activities. Therefore, the purpose of advertising is designed to form or maintain awareness of consumers of advertising and their interest in such a person or to promote the sale, purchase, rental of goods, or aimed at achieving the social result desired by advertisers. Taking into account the needs of society and the basic principles of the advertising industry, its popularity and necessity in modern society, the question of certain aspects of the implementation of advertising activities is relevant. In the context of their activities, advertisers or persons engaged in this type of promotion make significant mistakes. In particular, the sale of your product through the involvement of various types of intellectual property. In most cases, such errors are treated as infringements of intellectual property rights. In view of this, the topic is relevant and is the subject of research for research work. The article analyzes the concept of advertising as a type of information, identifies and analyzes its features and legal requirements for advertising as a type of information. Authors have identified promotional products as copyrighted. The normative-legal base of formation in the field of legal regulation of advertising was also analyzed.

Key words: copyright, object of copyright, advertising, advertising products.

У будь-який етап історичного розвитку інформування завжди мало велике значення. Що таке інформація і чому вона настільки важлива для будь-якого суспільства? За Академічним тлумачним словником, інформація становить «відомості про які-небудь події, чиюсь діяльність і т. ін.; повідомлення про щось» [1]. У свою чергу, знаходимо визначення інформації, закріплене на нормативно-правовому рівні у Законі України «Про інформацію». Відповідно до нього інформацію слід розуміти як «будь-які відомості та / або дані, які можуть бути збережені на матеріальних носіях або відображені в електронному вигляді» [2]. Той, хто інформував, мав великий вплив, а той, хто був проінформований, підпорядковувався певним чином такому впливу та керувався отриманою інформацією. Тому від змісту та якості інформування залежало багато фактів та обставин, що у сучасному світі є також дуже важливим.

Сьогодні реклама становить потужну платформу інформування населення, певних його груп щодо певного продукту чи діяльності задля його розповсюдження та популяризації. Задля повного аналізу та розуміння головних аспектів функціонування рекламної індустрії необхідно надати визначення категорії «реклама». Звертаючись до 
вже згаданого Академічного тлумачного словника, знаходимо визначення категорії «реклама»: це «популяризація товарів, видовищ, послуг і т. ін. з метою привернути увагу покупців, споживачів, глядачів, замовників і т. ін.» [1], що $є$ абсолютно відповідним визначенням, яке розкриває рекламу як механізм просування певного товару. У свою чергу, у Законі України «Про рекламу» закріплено таке визначення поняття «реклами». Це «інформація про особу чи товар, розповсюджена в будь-якій формі та в будь-який спосіб і призначена сформувати або підтримати обізнаність споживачів реклами та їхній інтерес до таких особин чи товару» [3]. На нашу думку, законодавче визначення $\epsilon$ більш змістовним і розширеним поняттям стосовно аналізу реклами як виду інформації, оскільки більш сучасно та цілісно розкриває основні аспекти сфери рекламування.

Проте поняття - це лише коротке та загальне трактування, а тому для повного опрацювання питання необхідно також виокремити ознаки реклами. Саме вони детально розкривають і характеризують сутність поняття. Зокрема, одразу зазначаємо, що рекламі властивий індивідуалізуючий характер. Це свідчить про те, що реклама є ніби складовою частиною інформації, іiі вузьким направленням. Можна констатувати, що уся реклама $є$ інформацією, проте абсолютно не вся інформація є рекламою. Виокремимо певні особливості, що є відмінними факторами.

Зокрема, інформація, яка використовується в рекламі, повинна спрямовуватися на певну групу осіб, категорію населення задля того, щоб мати результат та ефективність такого рекламування [4]. Це повинно бути розроблено та детально опрацьовано. Наприклад, рекламування риболовного знаряддя повинно бути поширене серед осіб чоловічої статі та розраховано на їхню увагу, якщо ж буде проінформований жіночий колектив, то результативність буде відсутня.

Всупереч цьому твердженню Закон України «Про рекламу» визначає, що рекламодавцям невідомі люди, коло осіб, на яких буде спрямована реклама, тобто споживачами такої реклами $є$ невизначене коло осіб. Спрямування на конкретне коло осіб відсутнє, з чим ми не погоджуємося [2], оскільки здебільшого створення реклами розраховане на певне визначене коло осіб, що є логічним і закономірним. Звісно, $є$ ті види реклами, які мають невизначене коло осіб і повинні привертати увагу всього населення незалежно від певних ознак.

Л. Микитенко пропонує дуже влучне визначення категорії «споживач реклами» - це фізичні або юридичні особи, на яких націлено рекламу і які мають намір придбати або замовити товар відповідної категорії, що продається суб'єктом господарювання або які вже використовують його [5, с. 39]. На нашу думку, таке визначення категорії $\epsilon$ узагальнюючим трактуванням на законодавчому рівні та виокремленим у доктринальних джерелах доцільного визначення споживачів реклами.

Ще однією ознакою $\epsilon$ те, що інформація «призначена сформувати або підтримати обізнаність споживачів реклами та їхній інтерес до таких особин чи товару». Ця особливість важлива для того, щоб відрізняти рекламу в юридичному розумінні цього слова від інших типів оголошень і повідомлень. Наприклад, не можна вважати рекламою публікацію комерційного банку його балансу за певний проміжок часу. Також реклама не повинна розглядатися як інформація, розповсюдження якої вимагається законодавством, іншими правовими актами, діловою практикою, рішеннями суду тощо [6, с. 86].

Тож важливим аспектом є приділення уваги на посил i призначення рекламних оголошень. Потрібно відмежовувати ціль реклами як інформаційного матеріалу та ціль iii розповсюдження, тобто мету такої рекламної діяльності. У першому випадку метою реклами в контексті інформації $\epsilon$ доведення до відома потенційних споживачів інформації про існування певного товару, товарного знаку або особи, спонукання думати про придбання товару та доведення споживача реклами до придбання товару.

Рекламна інформація націлена на формування чи підтримку інтересу до осіб, що згадуються в ній, і (чи) продукції, сприяє реалізації продукції, впливає на потенційних споживачів реклами, формує в них певне уявлення про конкретних фізичних і юридичних осіб, спрямована на невизначене коло споживачів. Отже, одержання прибутку є метою не реклами, а рекламодавця, для здійснення якої він і поширює рекламну інформацію, тобто здійснює рекламну діяльність. Тому мета реклами призначена сформувати або підтримати обізнаність споживачів реклами та їхній інтерес до такої особи чи сприяння продажу, купівлі, оренді товару або спрямована на досягнення соціального результату, бажаного для рекламодавців [4, с. 82].

Таким чином, можна зробити висновок про те, що реклама - це масштабна платформа інформування населення й окремих категорій осіб певних предметів, послуг, діяльності задля поширення такого продукту й отримання прибутку від цього в майбутньому. У ході нашого дослідження були виокремлені істотні особливості реклами загалом, на яких акцентував увагу і вітчизняний законодавець у контексті правового регулювання поширення інформації. Зокрема, до них було віднесено: спрямованість інформації на невизначене коло осіб, зміст інформації та ціль інформаційного впливу.

Поняття реклами містить у собі кілька аспектів функціонування та власного значення. Як вже зазначили вище, реклама - це вид інформації, за допомогою якої до людей доносяться певні матеріали та факти, так ії визначає і законодавець. Ураховуючи особливості процесу та внутрішнього механізму рекламування, це також вважається об'єктом авторського права.

Чому реклама вважається об'єктом авторського права, якщо виконує роль лише інформаційної функції та має комерційний характер? Рекламу потрібно розглядати як створену внаслідок творчої діяльності сукупність образів, ідей і рекламної інформації. Таким чином, це креативна й абсолютно індивідуальна робота, яка полягає у розробці ідеї, створенні певного продукту з нуля. Зокрема, з метою акцентування уваги на рекламі та, відповідно, на товарі, що рекламується, доволі часто рекламодавці використовують іiі яскравість, художність і музично оформлюють. Творчий підхід рекламодавця надає рекламі оригінальність та унікальність i, отже, відрізняє ії від багатьох інших рекламних повідомлень. Рекламне звернення, рекламний ролик або окремі його компоненти дедалі більше стають самостійним витвором мистецтва, на який поширюються авторські права. Текст реклами, який рекламодавець робить доступним, може майже не змінюватися, поки саме оголошення створюється у формі об'єкта авторського права.

Наприклад, рекламні буклети можуть містити фотографічні твори, оригінальні малюнки, які є об'єктами авторського права, але інформація про товар чи виробника буде викладена у формі звичайного текстового повідомлення. Коли рекламна інформація про товар, роботу чи особу, котра їх виробляє, надається у формі вірша, пісні, вона виступає самостійним об'єктом авторського права [7, с. 106]. Усе це відповідає усім ознакам об'єктів права інтелектуальної власності та підлягає під умови існування та функціонування як об'єктів авторського права, що регулюється Законом України «Про авторське право та суміжні права» [8]. Тому важливо розглянути авторську сторону реклами задля того, щоб цілісно і детально розглянути проблеми ऑiі функціонування, а також захищати авторів рекламної продукції від плагіату та незаконного використання їхніх проектів.

Однак не всі рекламні ролики можна класифікувати як такі, що захищені авторським правом. Для того, щоб такий об'єкт права інтелектуальної власності набув здатності авторсько-правової охорони, він повинен мати творчу 
складову частину, тобто творчий характер, а також має бути об'єктивізований (виражений в об'єктивній формі).

Закон захищає творця оригінального твору i надає йому виключне право виконувати, копіювати, розповсюджувати та демонструвати твір протягом певного періоду. Запис рекламного ролику створює оригінальний твір, представлений в аудіо- чи аудіовізуальному форматі. Рекламні гасла та гасла через свою малу форму та жанр також можна ототожнювати із творами усної народної творчості (фольклору), такими як народні приказки та прислів'я. Твори фольклору згідно 3 п. б ст. 10 Закону не захищені нормами авторського права.

Обов'язковою умовою визнання рекламного слогана об'єктом, захищеним авторським правом, є наявність креативного елемента незалежно від джерела цього слогану Довести існування творчого персонажа у творі невеликого змісту - непросте завдання. Якщо не доведено інше, результатом інтелектуальної діяльності вважається результат творчої праці [9]. Отже, рекламна продукція також вважається об'єктом авторського права через особливості процесу створення, що є важливим детермінуванням у зв'язку з основою iї правового регулювання й особливостей використання.

Правове регулювання $\epsilon$ основою керування та функціонування певної сфери чи галузі, у нашому випадку - саме рекламної індустрії. Важливим $є$ визначення й аналіз розвитку нормативно-правової бази у сфері правового регулювання реклами задля чіткого розуміння етапів формування сфери рекламної індустрії та законодавчо чинних основ функціонування цієї галузі.

Слід розглядати нормативно-правову базу в загальному та спеціалізованому аспектах. Загальні нормативноправові акти опосередковано визначають особливості рекламної діяльності. Такими $є$ насамперед Конституція України. ІІї норми формують загальну базу державного регулювання усієї рекламної діяльності загалом, як і будьякої іншої галузі зокрема. Відповідно до ст. 42 Конституції України «кожен має право на підприємницьку діяльність, яка не заборонена законом» [10]. Оскільки діяльність, пов'язана із рекламною, становить різновид підприємницької діяльності, вищезазначене положення безпосередньо розповсюджується і на рекламну діяльність. Слід також звернути увагу на первинну наявність тісного зв'язку між рекламною та підприємницькою діяльністю, відображену в Законі України «Про підприємництво» [11].

Ще один нормативно-правовий акт держави, який стосується регулювання підприємницької діяльності, орієнтованої на розповсюдження рекламної інформації, -
Закон України «Про підприємства в Україні» (втратив чинність). Зокрема, ст. 2 вищезазначеного Закону містила докладну класифікацію підприємств, серед яких було зазначено і малі підприємства, якими є переважна більшість суб'єктів рекламного бізнесу.

Підприємницька діяльність у сфері рекламного бізнесу також регулювалася Постановою Кабінету Міністрів «Про порядок державної реєстрації суб'єктів підприємницької діяльності» (втратила чинність), але ці нормативно-правові акти втратили чинність і не здійснюють ніякого впливу на регулювання рекламної діяльності, хоч зробили свій внесок у розвиток нормативно-правової бази правового регулювання рекламної індустрії $[12$, с. 126]. Важливо приділити увагу вузькоспеціалізованим нормативно-правовим актам, що регулюють рекламну діяльність конкретно спрямовано та детально. Закон України «Про рекламу» $є$ фундаментальним чинним законодавчим актом, який був прийнятий 3 липня 1996 р. та із сучасними змінами прямо регулює діяльність функціонування реклами та ії̈ особливостей [3]. Важливе місце в цій групі відводиться і Господарському кодексу України. Зокрема, в п. 1-2 ст. 33 містяться положення щодо неправомірного використання матеріалів рекламного характеру, введені вперше [13]. Окрім питань неправомірного використання рекламних матеріалів, важливим напрямом державного регулювання рекламної діяльності слід також вважати захист від недобросовісної реклами.

Первісне регулювання захисту суб'єктів господарювання та споживачів від випадків недобросовісної реклами здійснювалося Законом України «Про обмеження монополізму і недопущення недобросовісної конкуренції у підприємницькій діяльності» (втратив чинність). Фактично цей Закон був перший нормативно-правовим актом держави в Україні, в якому рекламна діяльність розглядалася як безпосередній об'єкт правового регулювання $[12$, с. 127]. Таким чином, нормативна база у сфері правового регулювання реклами є складною та досить розширеною. В Україні створена низка актів і документів, таких як Цивільний кодекс України, Господарський кодекс України, Кодекс України про адміністративні правопорушення, що окремими своїми положеннями регулюють відповідні сфери рекламування, хоч законодавством України визначений лише один нормативно-правовий акт Закон України «Про рекламу», який конкретно регулює рекламну діяльність. Вважаємо, що нормативно-правова база потребує вдосконалення та розширення стосовно видання спеціальних актів для регулювання суто рекламної індустрії.

\section{תITEPATYPA}

1. Академічний тлумачний словник української мови. URL: http://sum.in.ua/.

2. Про інформацію : Закон України від 02 жовтня 1992 р. № 2657-XII. Відомості Верховної Ради України. URL: https://zakon.rada.gov. ua/laws/show/2657-12\#Text.

3. Про рекламу : Закон України від 03 липня 1996 р. № 270/96-BP. Відомості Верховної Ради України. URL: https://zakon.rada.gov.ua/ laws/show/270/96-\%D0\%B2\%D1\%80\#Text.

4. Громенко Ю.О. До питання визначення поняття реклами. Проблеми правознавства та правоохоронної діяльності. 2006. № 4. C. $197-208$.

5. Микитенко Л. Правове регулювання реклами і рекламної діяльності: проблеми теорії. Підприємництво, господарство і право. 2003. № 10. С. $37-40$.

6. Громенко Ю.О. Розмежування реклами та інформації нерекламного характеру. Правничий часопис Донецького університету. 2011. № 2. C. $80-89$.

7. Ульянова Г.О. Реклама як складний об’єкт авторського права. Південноукраїнський правничий часопис. 2012. № 4. С. $105-108$.

8. Про авторське право і суміжні права : Закон України від 23 грудня 1993 р. № 3792-XII. Відомості Верховної Ради України. URL: https://zakon.rada.gov.ua/laws/show/3792-12\#Text.

9. Здоровець С. В. Реклама та її складові елементи як об'єкти авторського права. Протокол - юридичний інтернет ресурс. URL: https://protocol.ua/ua/reklama_ta_ii_skladovi_elementi_yak_ob_ekti_avtorskogo_prava/.

10. Конституція України від $2 \overline{8}$ червня 1996 р. № 254к/96-ВР. Відомості Верховної Ради України. URL: https://zakon.rada.gov.ua/laws/ show/254\%D0\%BA/96-\%D0\%B2\%D1\%80\#Text.

11. Про підприємництво : Закон України від 07 лютого 1991 р. № 698-XII. Відомості Верховної Ради України. URL: https://zakon.rada. gov.ua/laws/show/698-12\#Text.

12. Шведун В.О. Нормативно-правові засади державного регулювання рекламної діяльності в Україні. Інвестиції: практика та досвid. 2014. № 21. С. 125-129.

13. Господарський кодекс України від 16 січня 2003 р. № 436-IV. Відомості Верховної Ради України. URL: https://zakon.rada.gov.ua/ laws/show/436-15. 